\title{
Enhancing the Strategies of Climate Responsive Architecture, The Study of Solar Accessibility for Buildings Standing on Sloped Sites
}

\author{
Abdulsalam A. Alshboul ${ }^{1} \&$ Nabeel Y. Alkurdi ${ }^{1}$ \\ ${ }^{1}$ Department of Architecture, School of Engineering, The University of Jordan, Amman, Jordan \\ Correspondence: Abdulsalam A. Alshboul, Department of Architecture, School of Engineering, The University of \\ Jordan, Amman, Jordan. Tel: 962-79-600-8937. E-mail: alshboul@ju.edu.jo
}

Received: Sep. 30, 2018

Accepted: Oct. 16, $2018 \quad$ Online Published: December 11, 2018

doi:10.5539/mas.v13n1p69

URL: https://doi.org/10.5539/mas.v13n1p69

\begin{abstract}
One of the fundamental parameters for low energy architecture strategies implementations is to allow solar sun penetration into buildings, which can contribute to free heating in buildings and reduce energy consumption during cold season; through many design strategies that could be applied to buildings.

This is not easily achieved until a complete analysis of solar accessibility is done, which in turn enables us to decide whether such strategies are applicable or not.

Amman city is a case where such analysis is a must due to the problems of fuel scarcity and high fuel costs as well. In addition, the topographical nature of Amman city is not plain; rather it is almost mountainous, which makes it important to ensure solar accessibility on slope sites.

Much of modern apartments in Amman were built on sloped sites.

Method of research will depend on selected cases for solar radiation quantification for a number of cases including mainly modern residential buildings built on slope sites; this method will depend mainly on graphical analysis for solar penetration (INSOLATION) and theoretical calculations for the different cases.

Calculations of solar radiation were based on measured global irradiation, they were calculated for the under heated period for Amman; then a strategy were built to derive new set back values.

Recommendations will be as a set of rule of the thumb for direct application for the practicing architect, and they are reflected as new setback values between buildings. It will be the first step towards a complete set of regulations to ensure solar accessibility to buildings constructed on slope sites in Amman city and for other regions of similar slopes, looking for the target of maximizing solar radiation availability for minimizing fossil fuel consumption as an introduction to the study of sustainable buildings in Jordan.
\end{abstract}

Keywords: solar accessibility, building, slope site, climatic design, Jordan

\section{Introduction}

\subsection{Problem Description}

The concept of low energy architecture is an old one, and it goes back long time ago. Architecture was always to be concerned with solar radiation, solar cities through history were designed and constructed, many examples may be found in ancient Egypt, Chinese cities, and south American civilizations, Greek cities, (Behling and Sophia, 1996), and Roman cities, were this was first documented by the Roman architect Vitruvius, when he wrote his ten books. The French architect Le Corbusier was aware of the importance of such relationship, he wrote: "It is the mission of modern architecture to concern itself with the sun", (Letchner, 1990).

Architects were aware of the important relationship between sun and buildings; maximizing solar gains with strategies for energy conservation, gained attention since long time ago (O'callaghan P.W., 1978; Threlkeld J.L., 1970; Bruce A., 1977). Building applications for solar radiation utilization have been developed; as well, Jager F (1981) explained some of the most important methods and strategies.

In cold climates, sun is important to give free heat to buildings' indoors, while in hot climates, sun is not needed, rather indoor spaces should be protected from sun, because it is the main source of overheat, many design strategies deal with protection from sun during summer season (Watson D, Kenneth labs, 1983). 
Currently, the issue of energy and architecture is gaining more importance than before, due to several reasons, the first one is the fossil fuel resource depletion, the second is the environmental pollution resulting from fuel consumption; third, the instability of fuel supply and costs.

Many countries already started looking for new energy resources other than fossil fuels, the experiences of different countries may be found in (Schittich, 2003; Behling and Sophia, 1996, Sassi P., 2006).

Jordan as a developing country, is evidently with no natural energy resources nationwide, so it depends totally on imported fossil fuel, Jordan faces many problems related to fuel security supply on the national level, and this is reflected almost negatively upon the end use consumer, in which the Jordanian civilian suffers from instability of fuel supply, and if this happens, it is just with high fuel prices following the high international fuel prices.

Architecture in Jordan is strongly concerned with fuel security because the building materials extraction, construction industry, and building operations require fuel supply, with the ever increasing fuel prices it is so difficult to maintain acceptable comfort levels with minimum fuel consumption.

One of the most related factors to enhance low energy architecture is to establish a set of strategies and rule of the thumb regulations that can contribute to maximizing renewable energy utilization as a target to reduce fossil fuel consumption. In our work here we are mostly concerned with the incident solar radiation on residential facades; this is considered important if any regulations, policies, and obligatory procedures to be taken by the national public sector to make use of solar radiation utilization.

Jordan started many projects and policies regarding the organization for solar radiation profiting, and Jordanian Government is aware of the important interrelationship between fossil fuel supply and consumption on one hand and renewable energy resources on the other hand; in which they are aware of minimizing the first one, while maximizing the second.

Ministry of Housing and Public Works (MHPW) in cooperation with the Royal Scientific Society (RSS), started the preparation of building codes of practice to organize and control best practice regarding renewable energy resources to the benefit of architecture and building construction. The first building code to appear was "Code of Low energy buildings" which was prepared by the RSS and approved by the MHPW, was firstly published in the year 2007, the code tries to organize the relationship between building block volumes and openings as well as the orientation of buildings, solar collectors, solar Photovoltaics, and the like. The second building code to appear was, "Code of solar energy utilization", which is a further detailing of passive solar architecture, but is mainly focused on mechanical and technical issues related to heating and hot water installations.

A final code appeared in this series was "A guide to Green buildings in Jordan" related to illumination, mechanical and electrical installations, rain water harvesting; finally, natural ventilation and indoor air quality (Royal Scientific society, 2010).

A building which receives no solar radiation due to poor solar accessibility will not have any potential to apply passive solar techniques. So, before starting the application of any passive solar strategy, the architect must ensure that the sun reaches the building's facades, as a first step to apply passive solar techniques. After then, many passive solar strategies are available to be integrated with the building envelop (Steemers T.C., Palz W.) Houghton E. W., Turrent D., Whittaker C., 1981. (Williams R.J., 1983).

Importance of solar accessibility to buildings is not only for the purposes of heating and cooling; furthermore, it affects the luminous environment inside buildings, as availability of daylight will ensure minimum artificial lighting operation, which implies less electricity consumption and therefore, energy savings (Philips R.O., 1980).

Hachem C., Fazio P., Athienitis A. (2013) studied the effect of high density neighborhoods on solar accessibility to two storey residential building facades, for different residential buildings layouts and shapes, with solar accessibility maximization as a final target. Design guidelines and procedures were proposed as a final conclusion to this study, with an evaluation criteria based on weighted performance criteria.

Chan A.L.S., (2012), assessed the thermal performance of residential buildings in the case of varied shading on the facades of those buildings in Hong Kong; a final conclusion was that shading affected the thermal performance of the studied buildings. Similar work has been done by Julie Ann Futcher, Gerald Mills, (2013). Further related scientific work may be found, also Ylenia Cascone, Vincenzo Corrado, Valentina Serra (2011), Ays, egül Terecia, Soofia Tahira Elias Ozkana, Ursula Eickerb (2013).

J. Ramírez-Faz, R. López-Luque, (2012), developed an optical instrument that can determine obstructions like building and trees, or any other obstruction of any type, that obstruct solar radiation from reaching any point on a specific building façade, specifically, windows and glazed areas on building facades; which can be represented on 
different sun path diagrams, this gives the architect a tool to evaluate Insolation efficiency of buildings.

\subsection{Importance of the Problem}

The main objective of the research is to analyze and understand the relationship between the Great Amman Municipality (GAM) building regulations on the enhancement of low energy architecture strategies and solar utilization, because unless a certain amount of solar radiation reaches building facades, there will be no possibility to apply any of the designed solar passive strategies.

An individual building facing no obstructions will receive the total incident solar radiation, which may give the architect the possibility to qualify any passive solar design strategy; in case obstructions do exist in such a way that they obstruct solar radiation from reaching the building, there will be some difficulties in deciding whether a specific design strategy works well or not.

Setback distances between buildings, and the nature of land topography, make this task a little bit difficult.

One of the main objectives in our work here is to quantify probable solar radiation loss due to obstructions facing the targeted building façade.

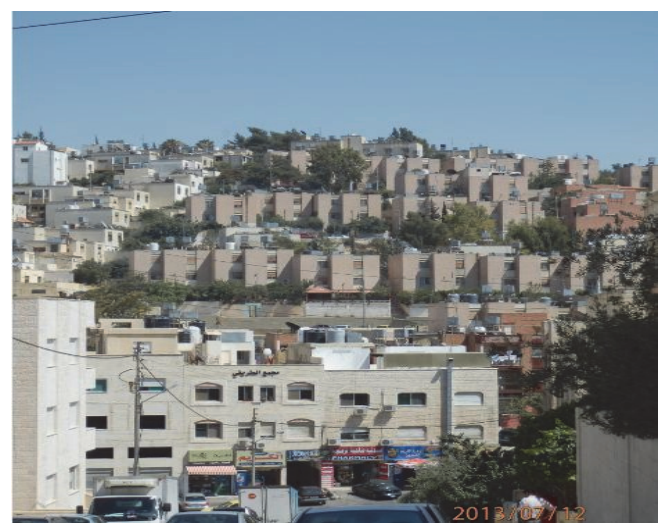

$\mathrm{a}$

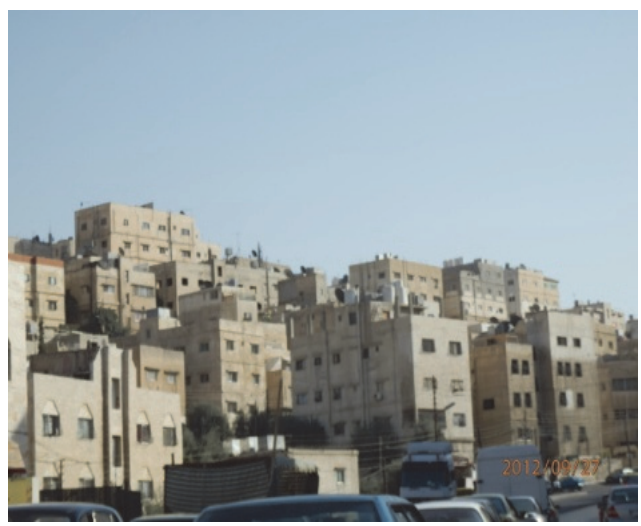

b

Figure 1. Topography of Amman city. A: shows buildings spread over topography. B: residential building blocks on sloped sites. (Source: Authors, 2013).

\subsection{Description of Relevant Scholarship}

Work of this type has been made by Alshboul and Alzoubi (2010) about the analysis of INSOLATION for flat sites (i.e. of $0 \%$ inclination). This work was not sufficient to generalize specific rules for GAM regions since Amman sites have certain degrees of inclination, figure no 1 . Further investigation is needed in this regard, and in our case, buildings standing on sloped sites, specifically those sites that have orientation due north. Further future work may be implemented for different cases.

In order to obtain a more comprehensive and reliable results for a well established rules and regulation for low energy architecture in Jordan, there still be a need to expand the results on a wider base, which means studying and analyzing the effects of GAM regulations on sloped sites. And this requires further work. Direct observation by the researchers shows that certain sloped sites do not receive solar radiation during the cold season, especially those sites oriented due north, north east and north west, which does not allow the owner or the architect to apply proper passive design techniques to buildings located on such site conditions.

\subsection{Hypotheses and Their Correspondence to Research Design}

Ensuring successful utilization of passive design techniques for solar energy use in buildings, require deep understanding of the building-site context, with its compliance with building regulations in a given location.

This work aims at understanding the relationship between buildings on sloped sites oriented to north, northwest, and north east in Amman city, this study will analyze cases related to north orientation only. How could we quantify solar radiation incident upon southern building facades in the above given case; further work may be expanded to cover other building orientations towards south.

The method will follow simulations for designed situations. The first option is selecting the site orientations under consideration; three residence categories in Amman available in GAM regions. This sort of experiment structure 
will enable to quantify solar radiation incident upon the facades of the selected building block which will give a first approximation to decide whether it is possible to use passive design techniques successfully or not.

The work will quantify the total solar radiation incident upon the southern facades during cold season, where solar radiation is much needed and desired, and this will be studied as a function of orientation and site slope.

This work is related to Amman city, latitude $32 \mathrm{~N}$, which means that it could be generalized to be valid for all positions on latitude $32 \mathrm{~N}$, considering the differences in solar radiation intensity and regional regulations for each locality.

\section{Method}

The experiment is designed to enable us understanding the relationship between Incident Solar Radiation on building facades facing south, while standing on sites oriented due north, which is a common topography in Amman, as an introduction to the study of climate responsive, green, and sustainable architecture. The experiment steps are summarized in the following:

First: the variable of topography, sloped sites were chosen starting from slight slopes $10 \%, 20 \%, 30 \%$, and $40 \%$ inclinations, all are due north. Sites of more than $40 \%$ are found in the topography of Amman, but due to research limitations work will be implemented just for the categories mentioned above.

Second: the variable of orientation, slopes oriented to North were selected to be studied.

Third: variable of residential categories, according to GAM, there are three main residential categories that must comply with during design and construction. In this research study, residences of category B were studied and analyzed. Each of the stated categories has specific setbacks as shown in table 1 below.

Fourth: analysis was conducted for Amman city climate; climatic data were taken from Amman meteorological station.

Table 1.Setbacks for residential land plots, categories A, B, C, and D.

\begin{tabular}{c|cccc}
\hline Residential category & Front setback & Side setback & Rear setback & Maximum built area (of total plot area) \\
\hline A & 5 & 5 & 7 & $36 \%$ \\
B & 4 & 4 & 6 & $42 \%$ \\
C & 4 & 3 & 4 & $51 \%$ \\
D & 3 & 2.5 & 2.5 & $52 \%$ \\
\hline
\end{tabular}

Fifth: further assumptions have been set, height of apartment was set to 3.0 meters. Setbacks were set to the maximum; this is because owners occupy the maximum land allowed for construction due to expensive land prices per unit area in Amman, and for investment purposes. Figure number 2 shows the experiment design according to the variables mentioned above.

Sixth: the study was restricted to a certain period of the year, were solar radiation is mostly needed for passive solar applications. The strategy based upon the fact that for any time period year round, when the external temperature drops below $15.5 \mathrm{C}$ is included in the under heated period, (i.e. winter time).

Based on this, climatic data showed that the start of under heated period was 15 November, and the end of under heated period was 15 April, and this is always for Amman city.

Another concern was that for the studied facades, it was assumed that there will be another building opposite to the façade under study, and therefore, it was considered as an obstacle that prevents solar radiation from reaching the building façade under study.

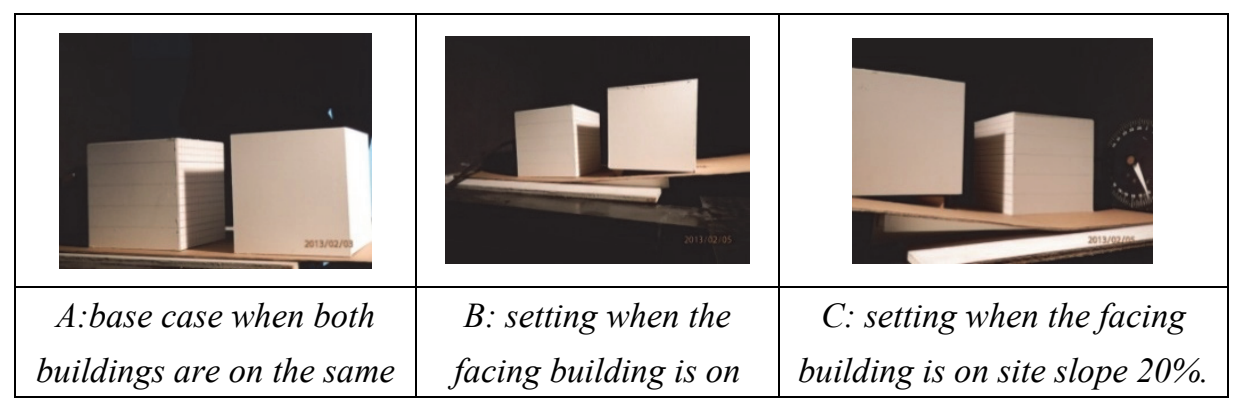




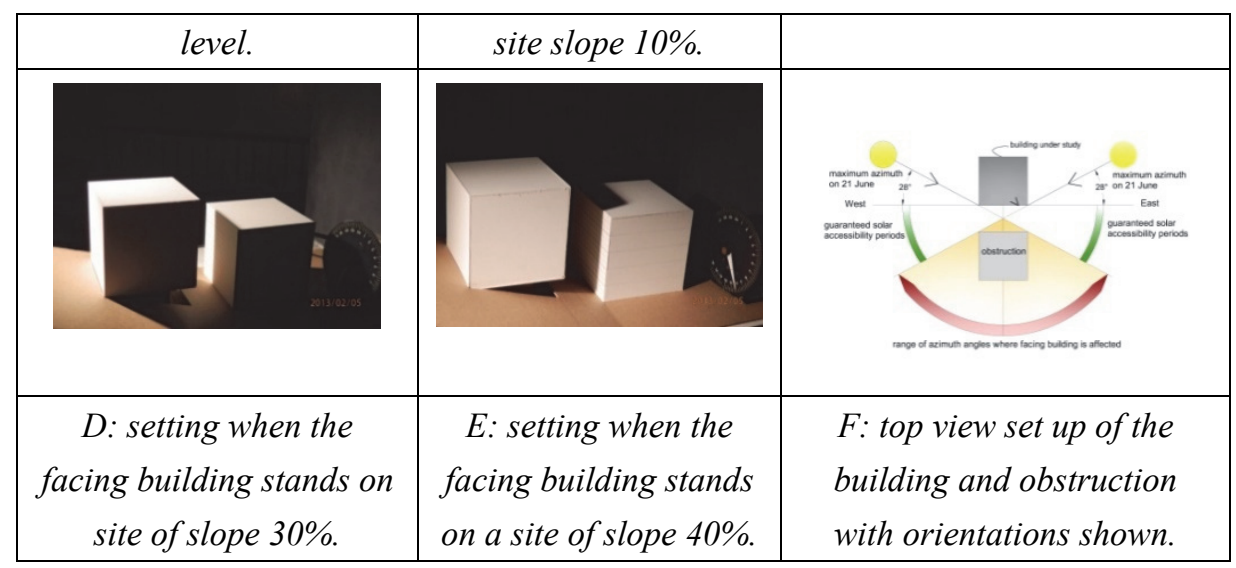

Figure 2. Variables settings, A) base case situation. B) Both buildings stand on a site of slope $10 \%$. C) Both buildings stand on a site of slope 20\%. D) Both buildings stand on a site slope of 30\%. E) Both buildings stand on a site of slope $40 \%$. F) Top view of both buildings showing distances according to GAM regulations.

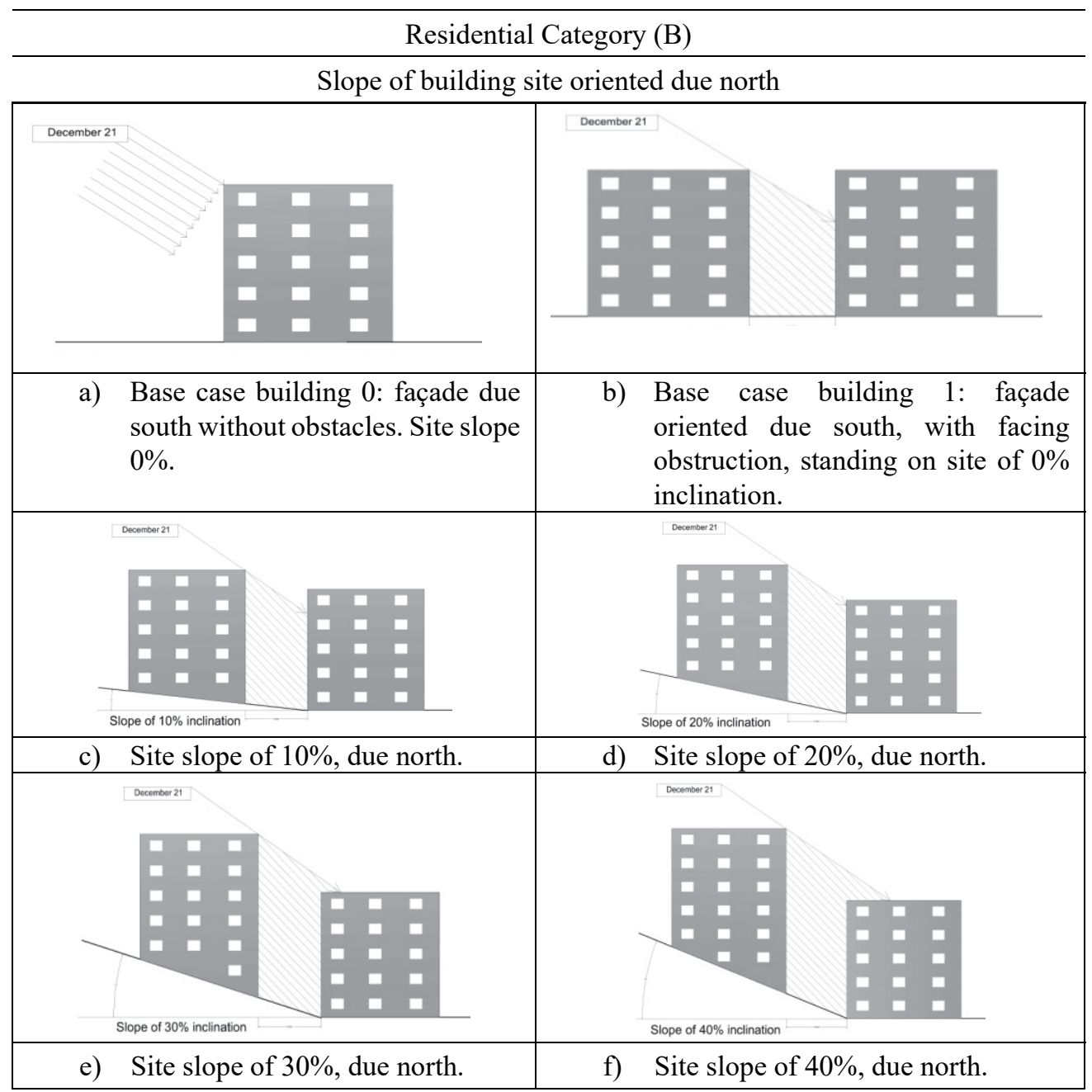

Figure 3. Different variables settings, residential category B, and site slopes direction due north, while building façade under consideration is due south. a) Base case building with $0 \%$ site slope without obstacles, and with a facing building in the second base case situation; b) site slopes $10 \%$ and $20 \%$. C) Site slopes $30 \%$ and $40 \%$.

(Source: Author, 2013) 


\section{Results}

\subsection{Variables Settings}

In order to understand the potentials of using solar energy on buildings facades, it is necessary to quantify energy received by facades under consideration, GAM regulations are the same for all sites in Amman even for sites of different slopes. This work is dedicated to analyze and understand the situation of residential zones of category B, other than residential zones A, C, and D. they may be explored in future work.

Site slopes in Amman city are rarely plain; rather they vary in slope from the very steep slope to almost plain sites. The following table shows a summary of variables settings that should guide energy calculations.

Table 2. Variables settings for the studied cases, Amman city, latitude $32 \mathrm{~N}$.

\begin{tabular}{ll}
\hline \multicolumn{1}{c}{ Variables setting } \\
\hline City: Amman. Latitude: $32^{\circ} \mathrm{N}$. Longitude: $36^{\circ} \mathrm{E}$. \\
Residential category: A, B, C, D. & Selected category: C \\
Site slope range & $0^{\circ}, 10^{\circ}, 20^{\circ}, 30^{\circ}, 40^{\circ}$. \\
Site slope orientation & Due North. \\
Building façade orientation & Due south. \\
Time period & Winter time, from 15 November -15 April, figure 4. \\
Day time period & From 8 am to $16 \mathrm{pm}$. \\
Number of days considered (winter period) & 151 days. \\
\hline
\end{tabular}

The method may be summarized in the following steps:

First, it is necessary to define the period in which solar energy is mostly needed, considering the importance of solar radiation year round, this period starts from 15 November and ends on 15 April, and this is always for Amman city. Based on Letchner (1990) definition of under heat period, according to Letchner, overheated period defined as all periods when average daily temperature is greater than $70^{\circ} \mathrm{F}$; while when average daily temperature is less than $60^{\circ} \mathrm{F}$. this considered as under heated period.

Second, calculation of the solar radiation received by building facades in the selected orientations without considering any obstacles that could obstruct solar radiation, and this will give the net solar radiation received.

Third, obstructions to be considered are those buildings being constructed according to the GAM regulations and they obstruct part or whole of solar radiation to be received by the studied building façade under consideration.

Fourth: the resulting net energy could be calculated by subtracting the obstructed façade area, which means reduction in received energy quantity, from the net energy received by the building without any obstruction.

Fifth, it is mostly possible to evaluate after then, the potentials of solar utilization, and the possibility of installing solar systems to those facades.

Sixth, it is possible to reevaluate the current regulations in terms of solar accessibility as an introduction to development for climate responsive buildings.

The following table 3 shows sun position during the period studied in Amman city.

Table 3. Definition of sun position during the total time period under consideration.

\begin{tabular}{lcccccc}
\hline \multicolumn{7}{c}{ Sun position definition for the whole period under study } \\
\hline \multicolumn{7}{c}{9 Tame of the day } \\
\hline \multicolumn{1}{c}{ Month } & altitude & azimuth & altitude & azimuth & Altitude & azimuth \\
\hline 21 December & 21 & 44 & 35 & 0 & 21 & 44 \\
21 January & 23 & 45 & 29 & 0 & 23 & 45 \\
21 February & 31 & 52 & 48 & 0 & 31 & 52 \\
21 March & 38 & 62 & 50 & 0 & 38 & 62 \\
\hline
\end{tabular}

Calculations will depend mainly on measured solar radiation by the Jordanian meteorological department Amman station. The following table shows measured solar irradiation for both components direct component and 
diffused as well.

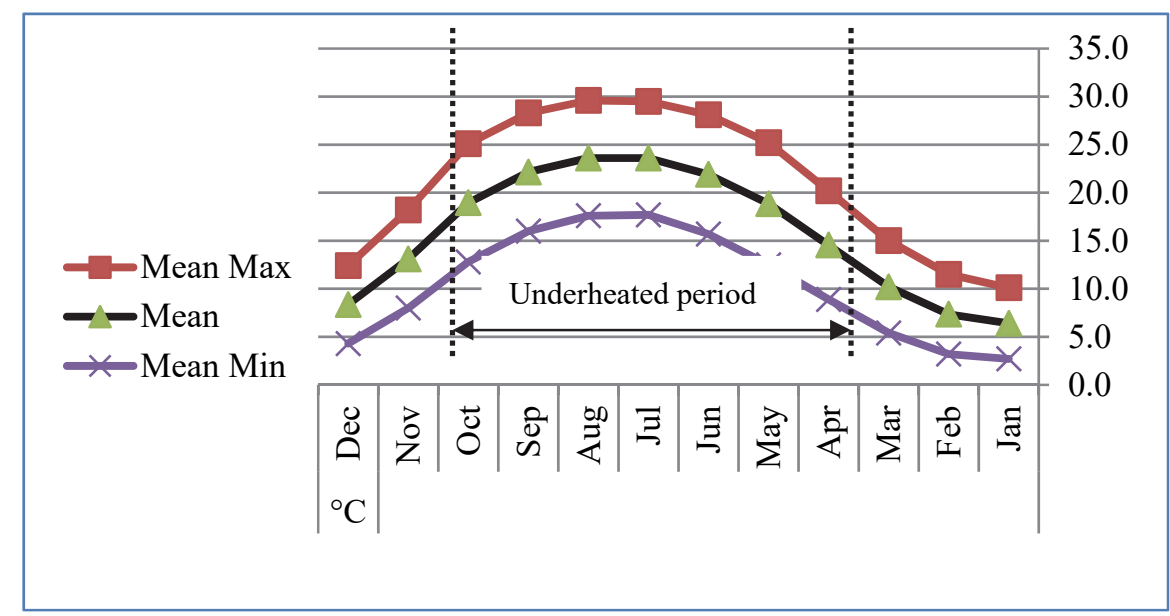

Figure 4. Average minimum, max, and mean temperatures for Amman city. (Source: Royal Scientific Society, 2010)

Figure 4 shows the start and end of under heat period for Amman city, according to temperature data obtained from Amman meteorological data, the first of November is the start of under heated period, and almost 15 April is the end of under heated period, where outside temperatures go below 15.5 C (Letchner,1990).

\subsection{Energy calculations for base case building without obstacles}

The continuous movement of sun through the day as a function of time requires establishing a mathematical model for energy quantification. Table number 2 , shows the definition of base case situation. This is well described as the typical façade width to be $15 \mathrm{~m}$, maximum height allowed for residential buildings of category B is four floors which implies a total block height of $15 \mathrm{~m}$, the building is oriented due south. A facing building of the same dimensions is located directly to the south of the base building, which is considered in our case as the obstacle that affects INSOLATION of the south façade in this case.

Table 4. Measured Mean monthly hourly global radiation on a horizontal plane, $\left(\mathrm{watt} / \mathrm{m}^{2}\right)$, Amman, Latitude $32 \mathrm{~N}$

\begin{tabular}{|c|c|c|c|c|c|c|c|c|}
\hline \multicolumn{9}{|c|}{$\begin{array}{l}\text { Measured monthly hourly mean global radiation on a horizontal plane }\left(\mathrm{W} / \mathrm{m}^{2}\right) \text {. } \\
\text { (winter time: } 15 \text { Nov-15 April), (Solar window: } 9 \text { am }-3 \mathrm{pm} \text { daily) }\end{array}$} \\
\hline \multicolumn{9}{|l|}{ Hour } \\
\hline Month & $8-9$ & $9-10$ & $10-11$ & $11-12$ & $12-13$ & $13-14$ & $14-15$ & $15-16$ \\
\hline November & 371 & 498 & 574 & 579 & 526 & 398 & 248 & 66 \\
\hline December & 198 & 302 & 339 & 338 & 302 & 259 & 158 & 56 \\
\hline January & 235 & 384 & 473 & 484 & 430 & 370 & 279 & 132 \\
\hline February & 287 & 438 & 549 & 594 & 536 & 479 & 382 & 156 \\
\hline March & 391 & 507 & 621 & 655 & 618 & 543 & 418 & 270 \\
\hline April & 551 & 724 & 833 & 884 & 849 & 753 & 621 & 424 \\
\hline
\end{tabular}

Source: Amman meteorological station, 2011). 


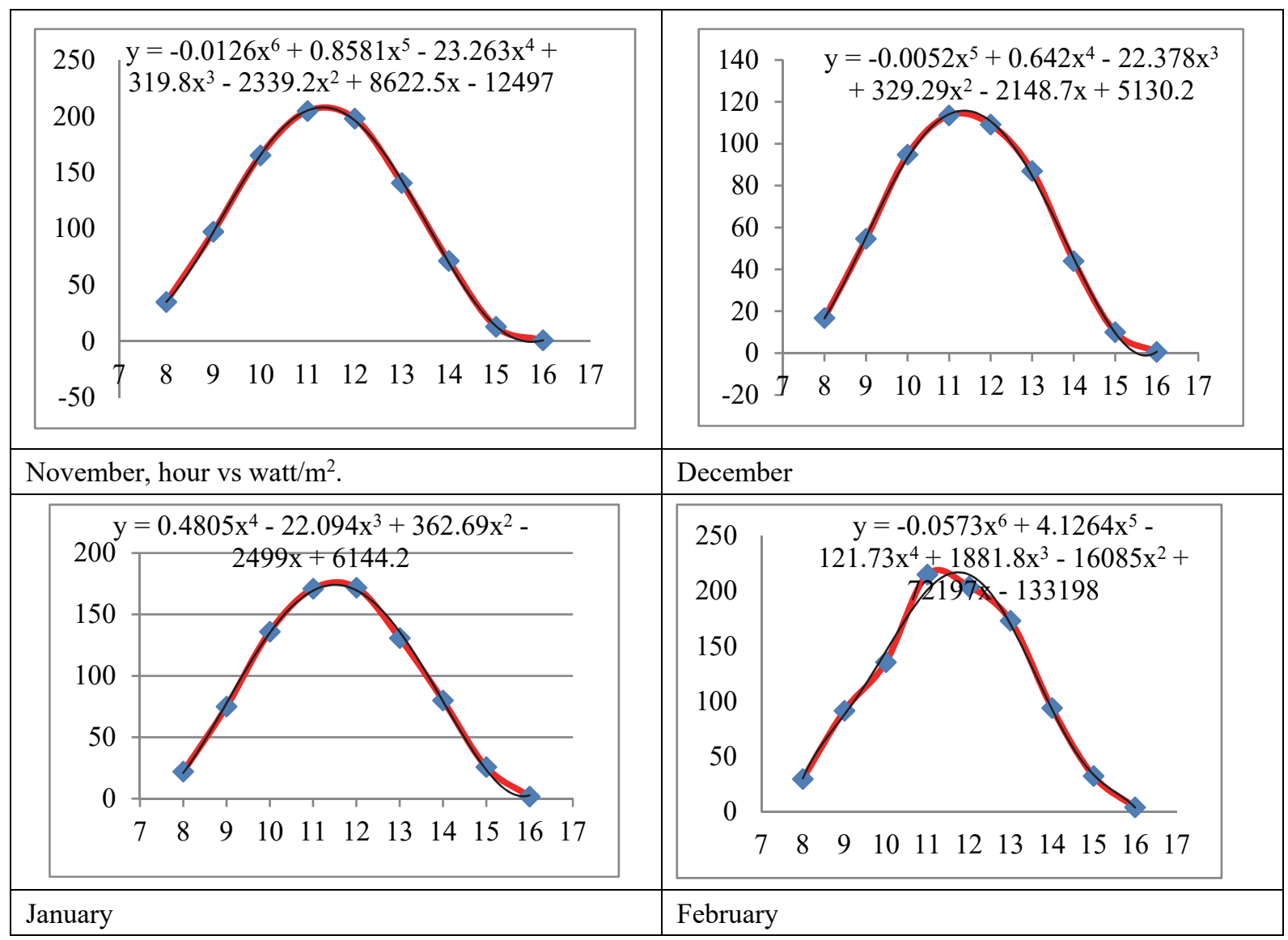

Figure 5. Direct solar radiation intensity $\left(\mathrm{W} / \mathrm{m}^{2}\right)$ on a vertical plane with facing obstruction, for base case 1 (slope $0 \%$ ), for November, December, January, February, and March. Where hours start from (8 am to $16 \mathrm{pm}$ ), regression equations are shown for each month

In order to obtain the direct component for solar radiation on a vertical surface, for the required period, which is the underheated period, the direct solar radiation should be calculated from the measured global radiation on a horizontal surface. This may be shown as follow:

$$
\begin{gathered}
\mathrm{I}_{\text {global }}=\mathrm{I}_{\text {direct }}+\mathrm{I}_{\text {diffused }} \\
\mathrm{I}_{\text {diffused }}=0.3\left[\mathrm{I}_{\text {direct }}\right]
\end{gathered}
$$

The factor of $(0.3)$ is the quantity of diffused radiation as a function of direct incident solar radiation on a horizontal surface (Chauliaguet C., Baratsabal P., Batellier J., 1977)

$$
\mathrm{I}_{\mathrm{global}}=\mathrm{I}_{\text {direct }}+0.3\left[\mathrm{I}_{\text {direct }}\right]=1.3\left[\mathrm{I}_{\text {direct }}\right]
$$

Then:

$$
\mathrm{I}_{\text {direct }}=\left(\mathrm{I}_{\text {global }}\right)(1.3)^{-1}
$$

Direct incident solar radiation on a horizontzl plane, $\left(\mathrm{I}_{0}\right)$ excluding diffused component is:

$$
\mathrm{I}_{0}=(1.3)^{-1}\left(\mathrm{I}_{\text {global }}\right)(\cos [90 \text {-altitude angle }])
$$

Where $\mathrm{I}_{0}$ is the direct solar radiation on a horizontal plane derived from the measured global solar radiation; using the equation number (5), we can obtain the received direct solar radiation on a vertical plane, and could be summarized in the following equation:

Substituting by $\left(\mathrm{I}_{0}\right)$, we get:

$$
\mathrm{I}_{\text {on vertical plane }}=\mathrm{I}_{0}(\cos [\text { altitude }])(\cos [\text { azimuth }])
$$

Solar radiation $\left(\mathrm{I}_{\text {vertical plane }}\right)=(1.3)^{-1}\left(\mathrm{I}_{\text {global }}\right)(\cos [90$-altitude $])(\cos [$ alt $])(\cos [$ azimuth $])$

Equation number (7) gives the value of direct solar radiation on a vertical plane based on measured global solar radiation on a horizontal surface. 
Departing from this point, it is possible now to go further in investigating the potentials of utilizating solar radiation on south facades considering obstacles such as neighboring buildings, located and distanced according to current GAM regulations. According to equation 7, figure 4 shows the derived average daily solar radiation on a vertical plane oriented due south. this will be decreased in varying percents when the plane is located on different solpes and obstacled by facing buildings.

Table 5. Direct solar radiation per unit area $\left(\mathrm{m}^{2}\right)$, on a vertical plane oriented due south, derived from measured hourly global radiation on a horizontal plane, refer to figure 5, Amman city, Latitude $32 \mathrm{~N}$

\begin{tabular}{|c|c|c|c|c|c|c|c|c|c|}
\hline \multirow{3}{*}{ Month } & \multicolumn{9}{|c|}{$\begin{array}{l}\text { Average hourly Direct solar radiation per unit area }\left(\mathrm{watt} / \mathrm{m}^{2}\right) \text { on a vertical plane, derived from } \\
\text { measured global solar radiation on a horizontal plane }\end{array}$} \\
\hline & \multicolumn{9}{|l|}{ Day time } \\
\hline & 8 & 9 & 10 & 11 & 12 & 13 & 14 & 15 & 16 \\
\hline November & 34.97 & 97.42 & 165.3 & 204.71 & 197.88 & 140.7 & 71.42 & 12.9 & 0.94 \\
\hline December & 16.76 & 54.6 & 94.77 & 113.57 & 109.2 & 87 & 44 & 10 & 0.6 \\
\hline January & 22 & 75 & 136 & 171 & 171.8 & 130.8 & 80 & 25.8 & 1.8 \\
\hline February & 29.8 & 91.6 & 135.5 & 214.7 & 204 & 173 & 94 & 32.6 & 4.2 \\
\hline March & 20 & 68.5 & 129 & 197 & 218 & 196 & 138 & 73 & 24.6 \\
\hline
\end{tabular}

\section{Discussion}

\subsection{Analysis}

Amman is located in central regions of Jordan; latitude $32 \mathrm{~N}$, the topographical nature of Amman does not guarantee effective solar utilization due to site inclinations and to the residential setback restrictions for a group of residential blocks.

Distances between buildings, maximum building heights, and building orientation restrict the way solar radiation utilization could be.

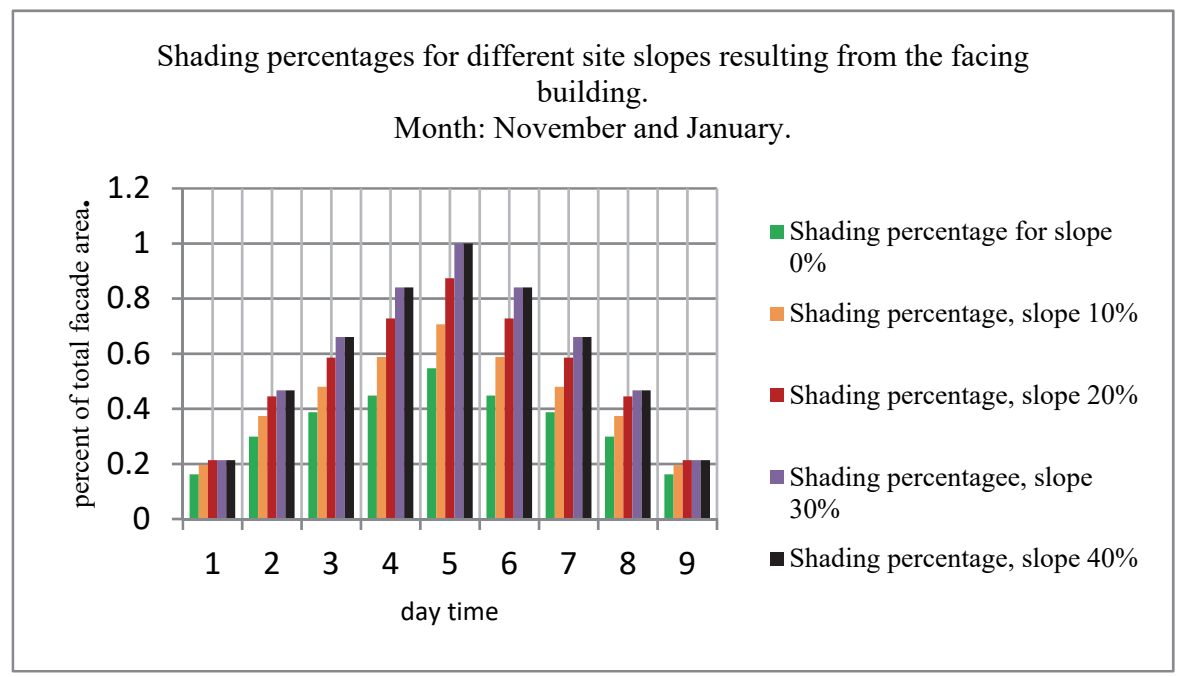

Figure 6. Percent of shaded area as a fraction of total façade area for the studied slope sites. Month: November and January. 


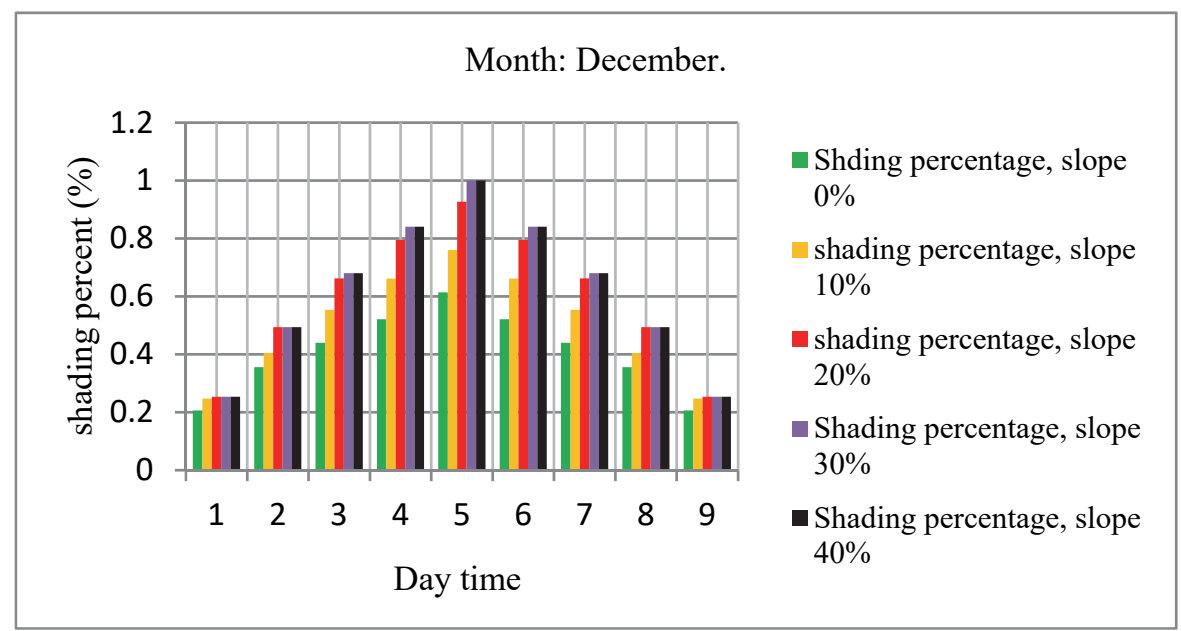

Figure 7. Percent of shaded area, as a fraction of total façade area, for the studied slope sites. Month: December.

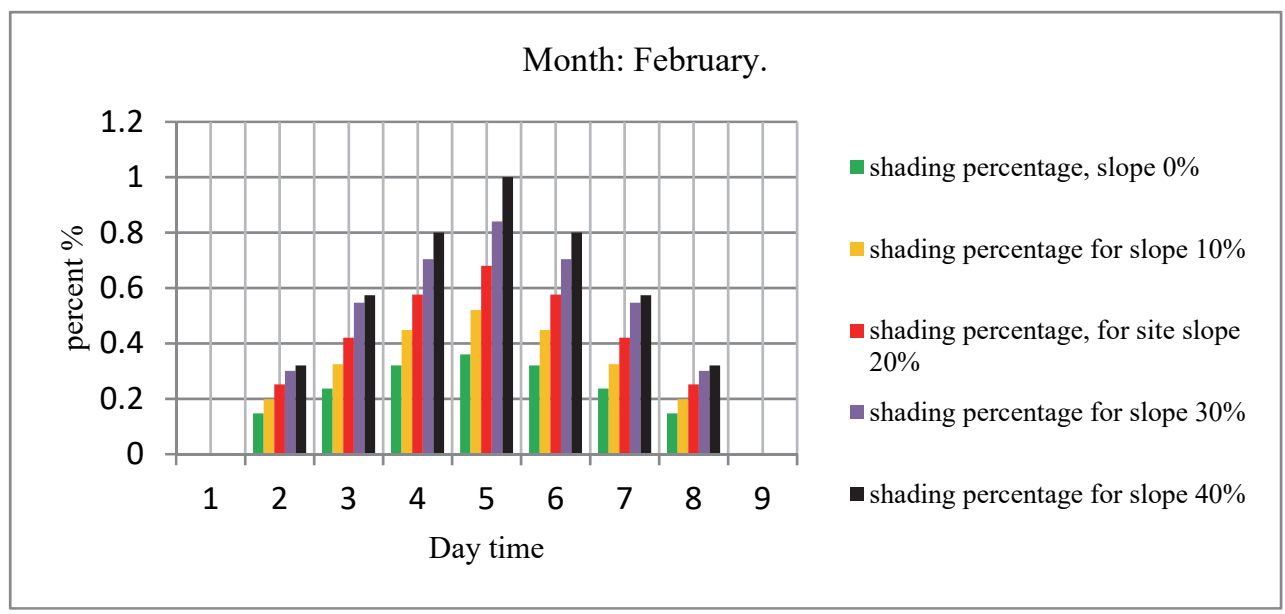

Figure 8. Percent of shaded area, as a fraction of total façade area, for the studied sloped sites. Month: February.

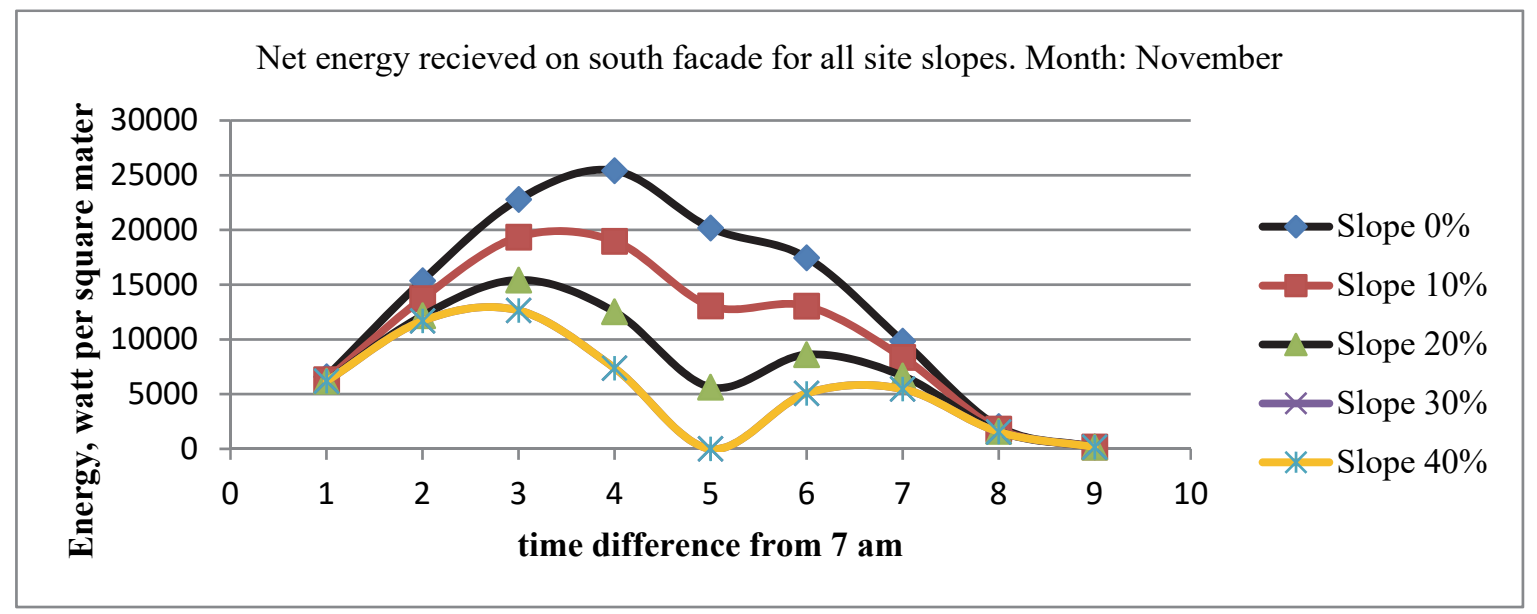

Figure 9. Incident energy on south façade, shown for the total assumed site slopes, including the base case - site slope $0 \%$, for November. 


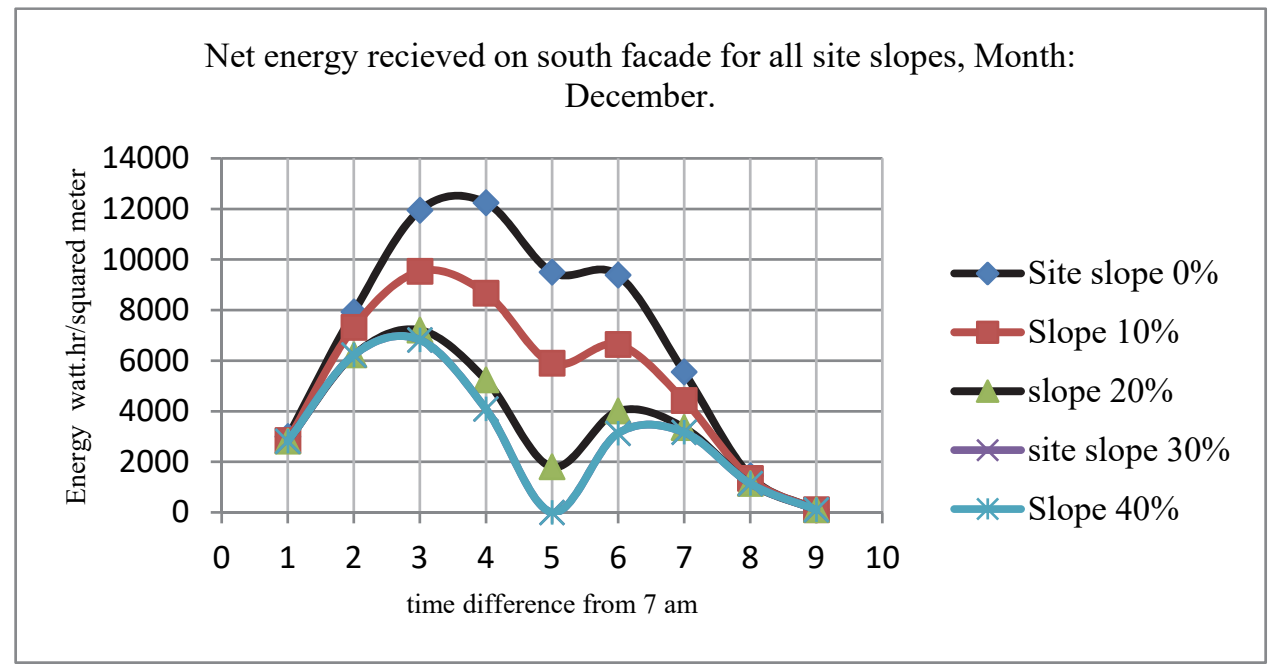

Figure 10. Incident energy on south façade, shown for the total assumed site slopes, including the base case site slope $0 \%$, for December.

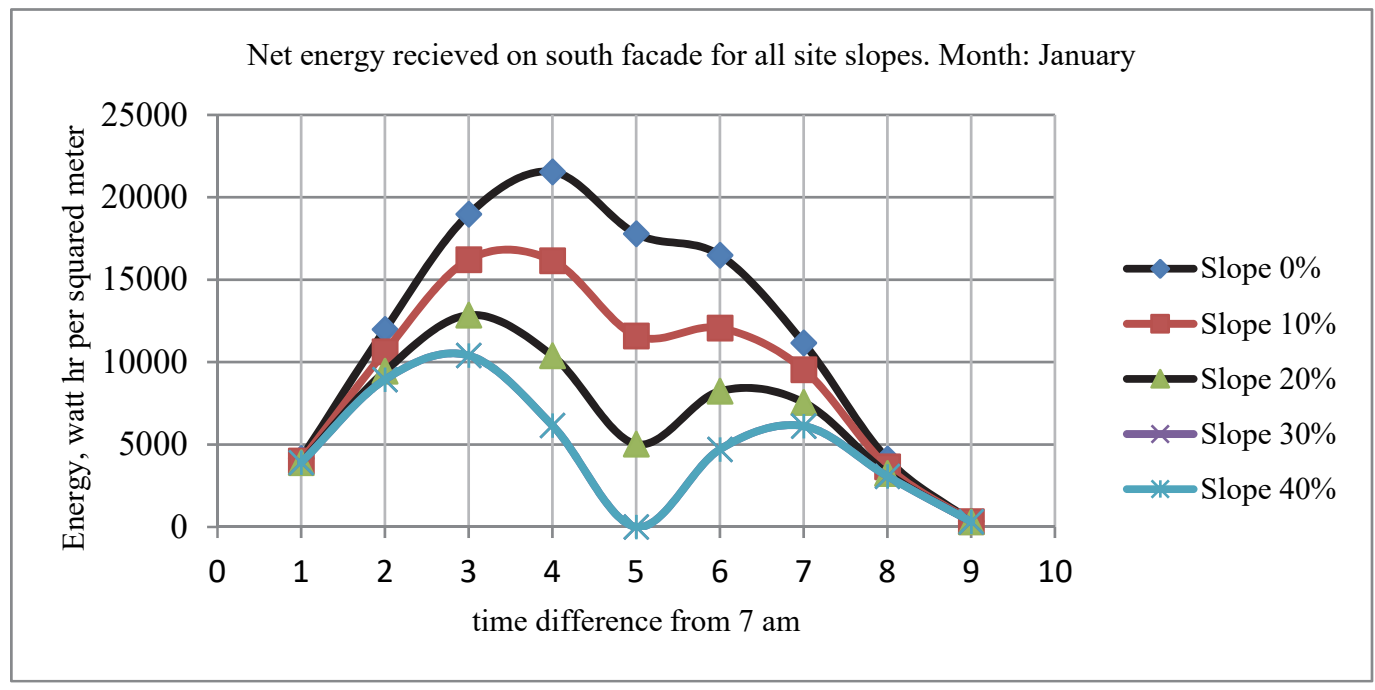

Figure 11. Incident energy on south façade, shown for the total assumed site slopes, including the base case site slope $0 \%$, for January

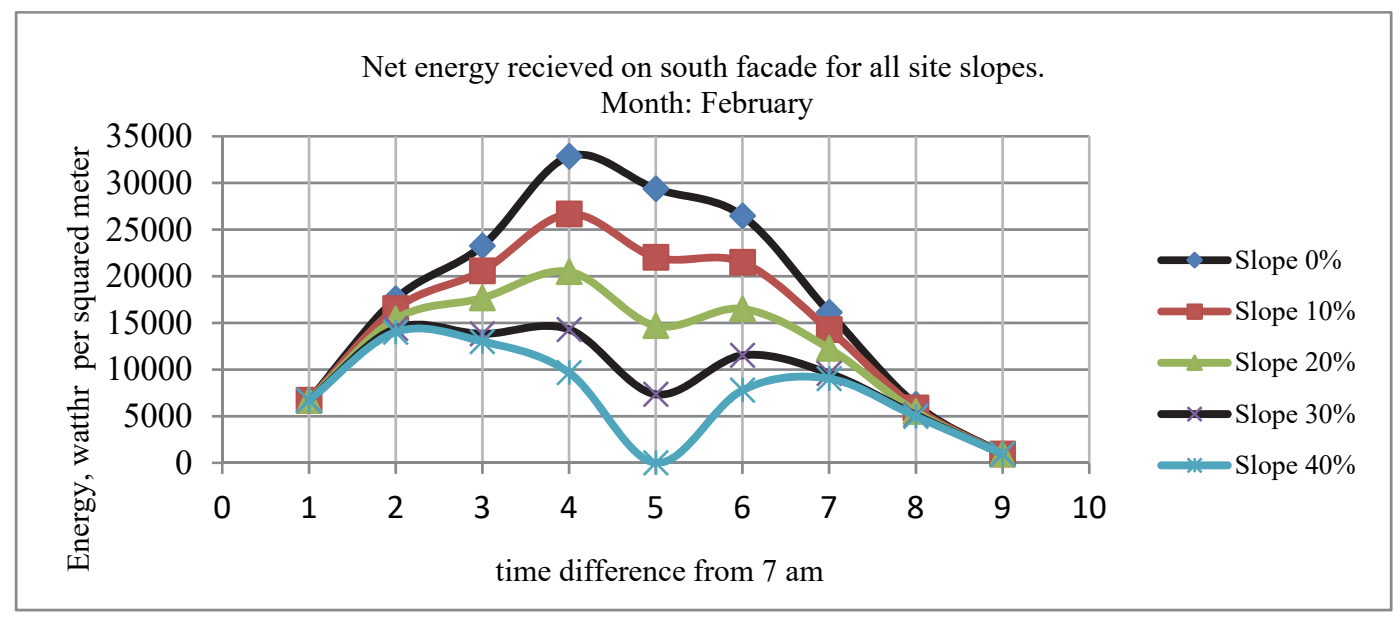

Figure 12. Incident energy on south façade, shown for the total assumed site slopes, including the base case site slope $0 \%$, for February 


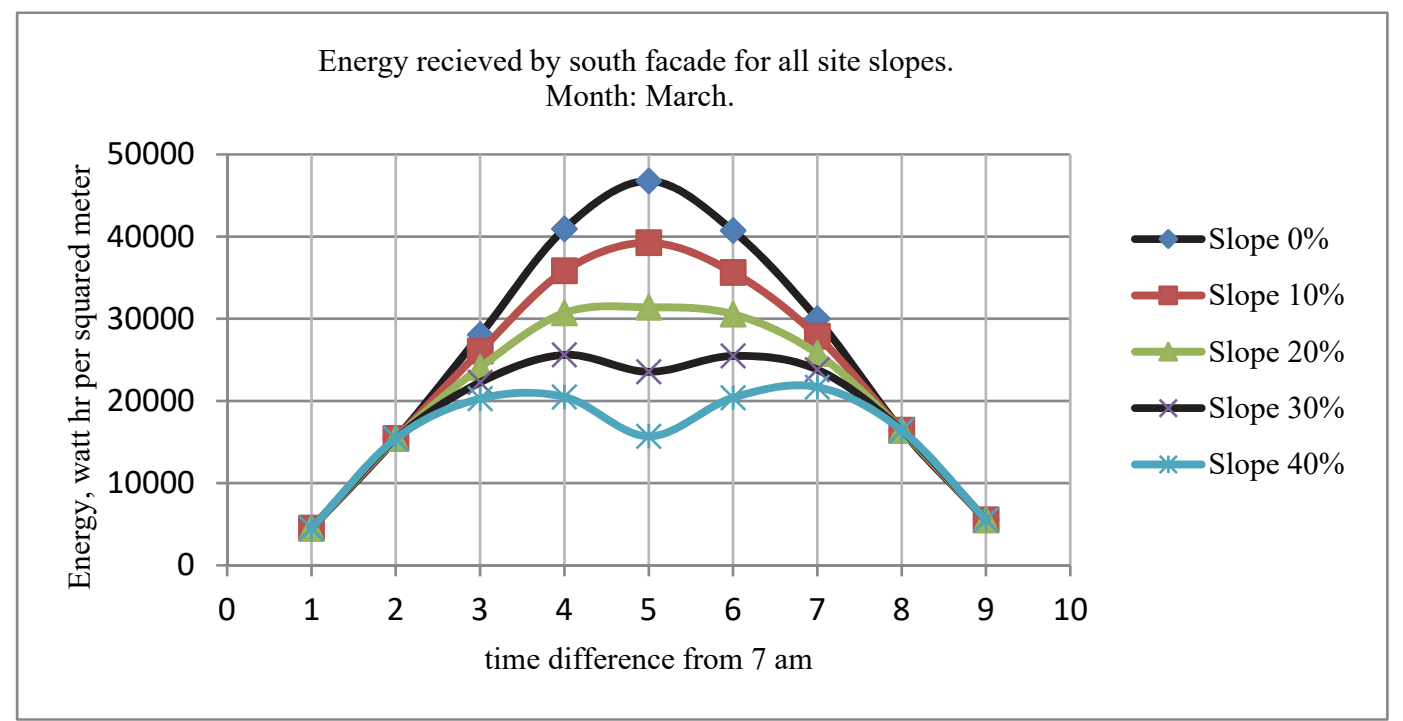

Figure 13. Incident energy on south façade, shown for the total assumed site slopes, including the base case site slope $0 \%$, for March

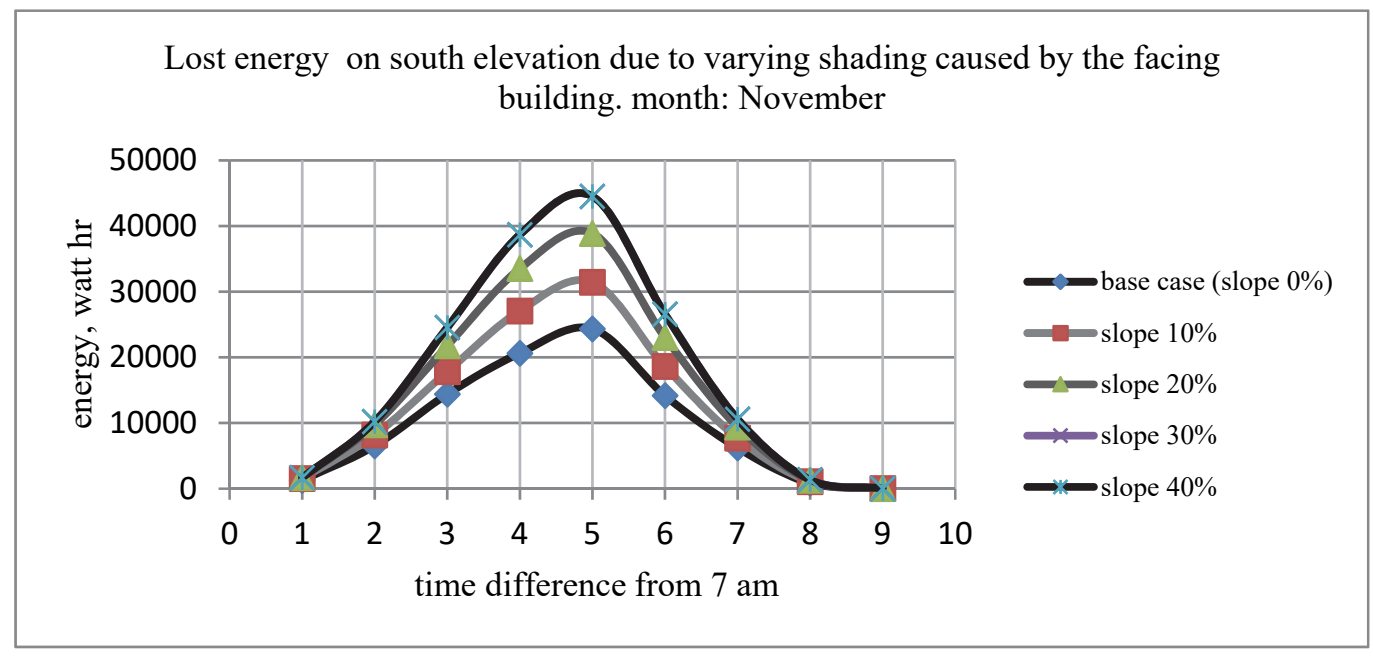

Figure 14. lost energy on the south façade of the base elevation, due to the facing building, shown for the total assumed site slopes, for November

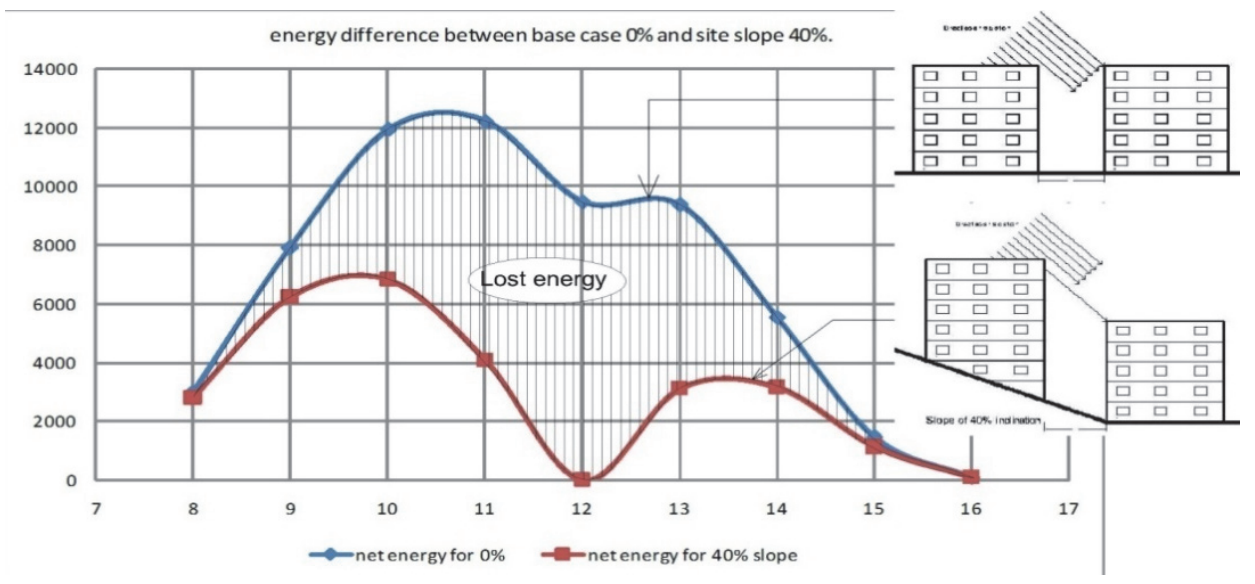

Figure 15. Lost energy as a result of facing obstruction in front of the façade under consideration 
As the study is concerned only for analyzing solar radiation on south facades, the calculated solar radiation will be only for the incident solar radiation on south facades, solar radiation was calculated without obstructions first; then, solar radiation was calculated with an existing obstruction as shown in figure 16, on a plane land plot, as a base case. It is worth saying that the curves are not symmetric, simply because the solar radiation intensity varied every moment day round.

In this case, lost energy as a result of the facing obstruction may be quantified by finding the total summation of the lost energy each hour, per day, per month for the whole under heated period, figure 15 . This may be expressed as:

$$
\text { Total Lost Energy (TLE) }=\sum_{i=1}^{m=4} \sum_{j=1}^{d=30 h=6}\left[\sum_{k=1}\left[\text { Energy }_{i j k}\right]_{b a \sec a s e 0 \%[]}-\left[\text { Energy }_{i j k}\right]_{\text {slopesite }\{10 \%, 20 \%, 30 \%, 40 \%\}}\right]
$$

Where:

$$
\begin{gathered}
I=1,2,3,4 . \\
J=\{1,2,3, \ldots . .30\} .
\end{gathered}
$$

$K=$ day hours from 9 am to $3 \mathrm{pm}$; (the total hours of the solar window).

\subsection{Set Back Improvements}

According to the previous analysis, it was evident that there are losses of solar radiation reaching the considered façade, due to the obstruction.

Therefore, it is necessary to look for a solution to reduce these energy losses. In the analyzed case, the total distance between the façade and the facing obstruction was 8 meters, which is the mandatory setback value that should be respected. And a look at the graphs of hourly energy we note that in December, maximum losses of energy are evident.

In order to get a new improved setback values, so that we can reduce total energy losses, the following procedure was developed:

First, The worst month in the under heated period was December, data obtained from the energy calculations for this month was adopted.

Second, For December, two values were considered; the first value is hourly irradiation received by the façade in the base case, where both the façade and the obstruction are laid on a flat plane $(0 \%)$. The second value is the irradiation received by the façade, where both the façade and the obstruction are located on four categories of site slopes, $10 \%, 20 \%, 30 \%$, and $40 \%$.

The summation of the difference between both values was considered, as shown in figure 15 , the following equation quantifies:

$$
\text { Lost Energy }=\sum_{i=1}^{n=9}\left(\text { Energy }_{(b a \sec a s e 0 \%)}\right)_{i}-(\text { Energy })_{i}
$$

Where: $\mathrm{I}=$ time difference from 7 am, $\mathrm{I}=\{1,2,3,4,5,6,7,8,9\}$.

The proposed procedure for improving the setbacks is summarized in the fact that an energy reduction factor is computed, then this reduction factor is reflected as an increase in setback value, so that the new proposed setback value can compensate the lost energy in the current setback value; the energy reduction factor is calculated as follow:

$$
\text { Energy Reduction Factor }=\left[\sum_{i=1}^{n=9}\left(\text { Energy }_{(\text {basec ase } 0 \%)}\right)_{i}-(\text { Energy })_{i}\right] /\left[\sum_{i=1}^{n=9}\left(\text { Energy }_{(\text {ba } \sec \text { ase } 0 \%) i}\right] \times 100 \%\right.
$$

Then, the improved setback $=X+[$ Energy Reduction Factor $\times(\mathrm{X})](11)$.

Where:

$X=$ the current setback for the residential category $\mathrm{C}$, the value of $\mathrm{X}$ in this case is $4 \mathrm{~m}$.

The analysis was assumed for north orientation, day time from 9 am until $3 \mathrm{pm}$. The research intention aimed at understanding the situations where efficient Insolation occurs and to arrive at improved setback values for 
residential category (C), which enable for efficient and useful passive design techniques applications.

Figure 16 shows two variables, the first variable $(\mathrm{X})$ describe the rear setback for $(\mathrm{C})$ residential category; while the variable (Y) describes the obstruction, which is in our case a facing building that should be complied with GAM regulations.

In the base case, energy was calculated, and it was assumed that the received energy on the south façade is a base value that could be used as a reference value.

For other inclined sites, the reduction in energy due to site inclinations and obstructions is taken as a base to develop new improved setback values; this is shown clearly in equations 10 and 11.

The final outcome of this analysis is summarized in table 5 , where for the four studied categories, the new improved setback shown for each category.

It is worthy to say that the variable $(\mathrm{Y})$ is assumed to be fixed. Otherwise, varying $\mathrm{Y}$ will result in different values. The reason beyond keeping the variable $\mathrm{Y}$ fixed, is that there is no intention to reduce $\mathrm{Y}$ less than the current building height; on the contrary there is a trend to increase this $\mathrm{Y}$ value. In this case it was assumed that it is better to have fixed $\mathrm{Y}$ variable, please refer to figure 16.

These conclusions and recommendations affect to a great extent the future decisions and policies related to the energy national policy. The basis on which the current setbacks were established do not relate to the concept of energy savings in buildings; given the fact that Jordanian Government is intensely concerned with the concept of low energy architecture; such conclusions may have great effect on the policy maker in Jordan.

Yet, many other parameters still needed to be studied and analyzed so that a complete set may be ready to be adopted by the policy maker in order to offer a highly climate responsive buildings.

Finally, the research is still open to several possibilities for studying different orientations and different facades, other orientations like those of north east and north west are still need more investigations. It is of great importance to pay attention that very steep slopes in Amman do exist, i.e. more than $40 \%$ percent, slopes like $45 \%$ and even $50 \%$ may be found in the topography of Amman and they are still used to grow buildings on.

Table 6. The final improved setback values based on energy calculations, compared to the base case condition, where the building façade and the obstruction are located on a $0 \%$ slope site; values calculated for December as worst case.

\begin{tabular}{|c|c|c|c|c|}
\hline AR & AS & AT & AU & AV \\
\hline & & & & \\
\hline \multicolumn{5}{|c|}{ Lost energy as a result of site slopes, measured from a base case where building and obstruction are located on $0 \%$ site slope. } \\
\hline & \multicolumn{4}{|c|}{ Watt hour } \\
\hline hour & Energy (0\%6)-Energy (10\%) & Energy (096)-Energy (2096) & Energy (096)-Energy (3096) & Energy (096)-Energy (4096) \\
\hline 8 & 152.8512 & 178.3264 & 178.3264 & 178.3264 \\
\hline 9 & 606.06 & 1696.968 & 1696.968 & 1696.968 \\
\hline 10 & 2416.635 & 4736.6046 & 5123.2662 & 5123.2662 \\
\hline 11 & 3577.455 & 7011.8118 & 8156.5974 & 8156.5974 \\
\hline 12 & 3603.6 & 7698.6 & 9500.4 & 9500.4 \\
\hline 13 & 2740.5 & 5371.38 & 6248.34 & 6248.34 \\
\hline 14 & 1122 & 2199.12 & 2378.64 & 2378.64 \\
\hline 15 & 111 & 310.8 & 310.8 & 310.8 \\
\hline 16 & 5.472 & 6.384 & 6.384 & 6.384 \\
\hline Total summation & 14335.5732 & 29209.9948 & 33599.722 & 33599.722 \\
\hline
\end{tabular}

\begin{tabular}{|l|l|l|l|l}
\hline Improvement factor & 0.234653331 & 0.478126859 & 0.549980569 & 0.54 \\
\hline
\end{tabular}

\begin{tabular}{|c|c|c|c|c|}
\hline Added value & 1.877226652 & 3.825014875 & 4.399844551 & 4.3998 \\
\hline Current GAM setback value (X) & $2 \times(4)$ & $2 \times(4)$ & $2 X(4)$ & $2 X(4)$ \\
\hline new (X) value & 9.877226652 & 11.82501487 & 12.39984455 & 12.3998 \\
\hline Site slope due north & $10 \%$ & $20 \%$ & $30 \%$ & $40 \%$ \\
\hline
\end{tabular}




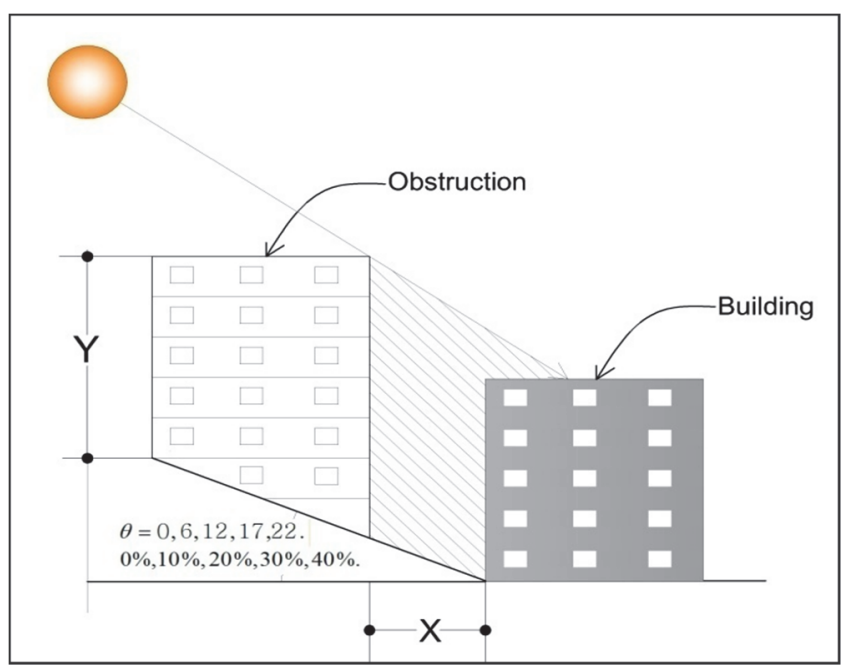

Figure 16. Obstruction height $(\mathrm{Y})$, (which is a facing building in this case); and the setback distance $(\mathrm{X})$, in which improved set back $(\mathrm{X})$ values are calculated and they are shown in the following table

\section{Acknowledgement}

Thanks dedicated to The University of Jordan for their continuous support; also many thanks go to undergraduate students for their contribution in preparing some drawings and figures.

\section{References}

Ays, E. T., Soofia, T. E., \& Ozkana, U. E. (2013). Energy benchmarking for residential buildings. Energy and Buildings, 60, 92-99.

Behling, S., \& Sophia (1996). Sol power the evolution of solar architecture. Prestel, New York.

Bruce, A. (1977). Solar energy: fundamentals in building design. McGraw-Hill book company, NewYork.

Caroline, H., Paul, F., \& Andreas, A. (2013). Solar optimized residential neighborhoods: Evaluation and design methodology. Solar Energy, 95, 42-64.

Cascone, Y., Corrado, V., \& Serra, V. (2011). Calculation procedure of the shading factor under complex boundary conditions. Solar Energy, 85, 2524-2539.

Chan, A. L. S. (2012). Effect of adjacent shading on the thermal performance of residential buildings in a subtropical region. Applied Energy, 92, 516-522.

Chauliaguet, C., Baratsabal, P., \& Batellier, J. P. (1977). Solar energy in buildings, John Wiley and Sons, NewYork.

Jager, F. (1981). Solar energy applications in houses, performance and economics in Europe, published for the commission of the European communities. Pergamon Press, NewYork.

Julie, A. F., \& Gerald, M. (2013). The role of urban form as an energy management parameter. Energy Policy, 53, 218-228.

Letchner, N. (1990). Heating cooling lighting design methods for architects, John Wiley \& Sons, New York.

O'callaghan, P. W. (1978). Building for energy conservation, Pergamon press, Oxford.

Palz, W., Steemers, T. C., Houghton-Evans, W., Turrent, D., \& Whittaker, C. (1981). Solar houses in Europe, how they have worked, Pergamon press, Oxford.

Paola, S. (2006). Strategies for sustainable architecture. Taylor \& Francis, New York.

Philips, R. O. (1981). Making the best use of daylight in buildings. in: Cowan H.J., Solar energy applications in the design of buildings. Applied science publishers, London.

Ramírez-Faz, J., \& López-Luque, R. (2012). Development of a methodology for quantifying insolation variables in windows and building openings. Renewable Energy, 37, 426-433.

Royal Scientific Society. (2007). Code of low energy buildings, Ministry of housing and public works, Amman, Jordan. 
Royal Scientific Society. (2009). Code of solar energy utilization in buildings, Ministry of housing and public works, Jordan.

Royal Scientific Society. (2010). Guide for Green Buildings in Jordan. Ministry of housing and public buildings, Jordan.

Schittich, C. (2003). In detail solar architecture, strategies, visions, and concepts, Berkhausers - Publishers for architecture, Berlin.

Threlkeld, J. L. (1970). Environmental engineering. $2^{\text {nd }}$ edition, Prentice Hall, NewJersey.

Watson, D., \& Kenneth, L. (1983). Climatic design. McGraw-Hill book company, NewYork.

Williams, R. J. (1983). Passive solar heating. Ann Arbor Science publishers, Michigan.

\section{Copyrights}

Copyright for this article is retained by the author(s), with first publication rights granted to the journal.

This is an open-access article distributed under the terms and conditions of the Creative Commons Attribution license (http://creativecommons.org/licenses/by/4.0/). 